\title{
The Effectiveness of Application of Diversi During Covid-19 Pandemic Period in Balai Pemasyarakatan Kelas II Pekalongan
}

\author{
Royyan Mahmuda Al'Arisyi Daulay ${ }^{1, *}$ \\ ${ }^{1}$ Balai Pemasyarakatan Kelas II Pekalongan \\ ${ }^{*}$ Corresponden author. Email: royyanmahmuda@gmail.com
}

\begin{abstract}
Diversi is an effort to resolve cases written in Law Number 11 of 2012 concerning the Juvenile Criminal Court System. Diversi efforts are realized by bringing together children who are faced with the law and victims and other parties related to the goal of recovery. The implementation of diversi has been acknowledged by all law enforcement officials in Indonesia, including the Balai Pemasyarakatan Kelas II Pekalongan. However, since the emergence of the Covid-19 pandemic, the application of diversi in the juvenile criminal system has faced obstacles and challenges. The present study aims to identify the effectiveness of the application of diversi as a legal policy in the Child Criminal Justice System Act during the Covid-19 pandemic. This study uses a descriptive-analytic method with a qualitative-normative approach. Our data come from statutory regulations, legal theories, and interviews with informants from Bapas Kelas II Pekalongan. The results indicate that the application of diversi during the Covid-19 pandemic in Bapas Pekalongan environment has been running well despite several challenges and obstacles, such as constrained coordination between law enforcement officials due to social restrictions, constrained supervision when implementing the results of the diversi agreement and restricted access to social institutions as an effort to prevent the spread of the Covid-19 outbreak. Meanwhile, the recommendations offered include strengthening information technology as a solution to the coordination of law enforcement officials and maximizing the function of the village government as a partner to oversee the results of the diversi agreement.
\end{abstract}

Keywords: law, Balai Pemasyarakatan Kelas II Pekalongan, diversi, child criminal justice system and covid-19.

\section{INTRODUCTION}

After the implementation of Government Regulation Number 21 of 2020 concerning LargeScale Social Restrictions in the Context of Accelerating the Management of Corona Virus Disease (Covid-19), Indonesia has undergone very substantial changes in the context of national governance, whether on political, legal, social, cultural, and religious issues. Law enforcement is one of the aspects affected by this policy, such as the house assimilation program for prisoners in prison, restrictions on meetings during court proceedings, and other restrictions on not gathering large numbers of people in law enforcement activities.

Restrictions on law enforcement in the context of handling the Covid-19 pandemic are very good and wise steps. However, it causes problems in criminal matters, such as court proceedings and efforts to apply Diversi to juvenile crimes. Based on data from Bapas Kelas II Pekalongan, there has been an increase in criminal cases committed by children.[1]

In May 2020, Bapas Kelas II Pekalongan received 14 (fourteen) requests of social research for diversi in juvenile criminal cases. This demand is quite high compared to previous months, such as 7 (seven) cases in January, 4 (four) cases in February, 5 (five) cases in March and 1 (one) case in April.

Of the 14 (fourteen) cases handled by Bapas Kelas II Pekalongan in May 2020, 10 (ten) of them are still at school formally and are following the rules to comply with the home learning process. For this reason, the diversi process is sought to solve it. 
Normatively, when a child is faced with a crime, law enforcement officials will handle it based on Law Number 11 of 2012 concerning the Criminal Justice System for Children, thereby called is the SPPA Law. The fundamental difference between the handling of juvenile and adult crimes is the application of the principles of restorative justice.

In the child's criminal law, law enforcement officials are expected to revive relationships between victims and practitioners as they otherwise would. In fact, it is necessary to hold a meeting involving victims, perpetrators, and other related parties in the context of solving cases so that they may not end their child in prison terms. These efforts are known as Diversion and it is a key to the spirit of restorative justice.

The diversi effort departs from the paradigm of restorative justice in the SPPA Law which believes that imprisonment or retaliation for child offenders is not the right solution to solve the criminal problems that ensnare him. On the other hand, the imprisonment process allows children to be exposed to committing other crimes because they often interact with other adult inmates.[2]

The Covid-19 pandemic has indeed limited all aspects, but Diversi efforts for children who are faced with the law must still be implemented, considering that diversi is an effort to keep children away from imprisonment which may later cause negative impacts. The present study research aims to dig deeper into the problem of Diversi amid a pandemic, especially in its application which is limited by circumstances and policies.

This paper provides answer to the following questions:

1. How is the implementation of Diversi in Bapas Kelas II Pekalongan during the pandemic period?

2. How effective is the law of applying Diversi during a pandemic?

\section{RESEARCH METHOD}

This study uses a descriptive-analytic method, namely by collecting, classifying, and describing the data that appears as it is, followed by an in depth analysis to obtain the meaning behind the fact.[3]

The main data source of this research is Law Number 11 of 2012 concerning the Juvenile Criminal Justice System and information about the application of Diversi in Bapas Pekalongan. The secondary sources are theories of legal effectiveness and other theories related to this research.

This research uses a qualitative-normative approach. That is, this research explores in detail the sources of data derived from statutory regulations, legal theories, and also the results of interviews with informants from the Bapas Kelas II Pekalongan.

\section{FINDINGS AND DISCUSSION}

\subsection{The Implementation of Diversi In Bapas Pekalongan}

\subsubsection{Description of Bapas Kelas II Pekalongan}

Bapas Kelas II Pekalongan is one of the technical implementation units within the Regional Office of the Ministry of Law, Central Java. One of the duties and functions of the Correctional Center, as regulated in Law No. 11 of 2012, is to carry out assistance, community research, guidance, and supervision of children who conflict with the law (hereinafter referred to as $\mathrm{ABH}$ ).

This function requires the Correctional Center to always maintain communication and coordination with the Police, Attorney General's Office, and the Court. Even the recommendation of the Correctional Center which is contained in social research is an important factor and influences the Judge's decision.

According to data from the Directorate General of Corrections[4], in 2020 there are 77 Correctional Centers in Indonesia which are divided into 33 Provinces, namely:

Table I : Data Of Correctional Center In Indonesia

\begin{tabular}{|l|l|c|}
\hline No. & \multicolumn{1}{|c|}{ Province } & Units \\
\hline 1. & Aceh & 2 \\
\hline 2. & North Sumatra & 2 \\
\hline 3. & West Sumatra & 2 \\
\hline 4. & Jambi & 2 \\
\hline 5. & Riau & 1 \\
\hline 6. & Riau Island & 1 \\
\hline 7. & Bangka Belitung & 1 \\
\hline 8. & Bengkulu & 1 \\
\hline
\end{tabular}




\begin{tabular}{|c|c|c|}
\hline 9. & South Sumatra & 2 \\
\hline 10. & Lampung & 2 \\
\hline 11. & Banten & 3 \\
\hline 12. & DKI Jakarta & 4 \\
\hline 13. & West Java & 4 \\
\hline 14. & Central Java & 8 \\
\hline 15. & East Java & 7 \\
\hline 16 & DIY & 2 \\
\hline 17. & Bali & 2 \\
\hline 18. & East Nusa Tenggara & 2 \\
\hline 19. & West Nusa Tenggara & 2 \\
\hline 20. & East Kalimantan & 2 \\
\hline 21. & West Kalimantan & 2 \\
\hline 22. & Central Kalimantan & 3 \\
\hline 23. & South Kalimantan & 3 \\
\hline 24. & South Sulawesi & 3 \\
\hline 25. & North Sulawesi & 1 \\
\hline 26. & West Sulawesi & 1 \\
\hline 27. & South East Sulawesi & 2 \\
\hline 28. & Central Sulawesi & 2 \\
\hline 29. & Gorontalo & 1 \\
\hline 30. & Maluku & 2 \\
\hline 31. & North Maluku & 1 \\
\hline 32. & Papua & 2 \\
\hline 33. & West Papua & 2 \\
\hline
\end{tabular}

The working area of Bapas Pekalongan will be described in the table below[5] :

Table II: State the source of data and year

\begin{tabular}{|l|c|c|}
\hline NO & Regency/City & $\begin{array}{c}\text { LUAS } \\
\text { WILAYAH }\end{array}$ \\
\hline 1. & Regency of Batang & $788,64 \mathrm{Km}^{2}$ \\
\hline
\end{tabular}

\begin{tabular}{|c|c|c|}
\hline 2. & Regency of Pekalongan & $\begin{array}{c}836,13 \\
\mathrm{Km}^{2}\end{array}$ \\
\hline 3. & City of Pekalongan & $45,25 \mathrm{Km}^{2}$ \\
\hline 4. & Regency of Pemalang & $\begin{array}{c}1.115,30 \\
\mathrm{Km}^{2}\end{array}$ \\
\hline 5. & Regency of Tegal & $878,7 \mathrm{Km}^{2}$ \\
\hline 6. & City of Tegal & $39,68 \mathrm{Km}^{2}$ \\
\hline \multirow[t]{2}{*}{7.} & Regency of Brebes & $\begin{array}{c}1.662,96 \\
\mathrm{Km}^{2}\end{array}$ \\
\hline & Total & $\begin{array}{c}5.366,66 \\
\mathrm{Km}^{2}\end{array}$ \\
\hline
\end{tabular}

With an area of $5,366.66 \mathrm{Km}^{2}$, consisting of 7 (seven) Regencies / Cities on the north coast of Central Java, Bapas Pekalongan is supported by fairly limited resources, consisting of 4 (four) Structural Officials, 6 (six) Administrative Positions, 26 (twenty-six) Functional Position Pembimbing Kemasyarakatan \& Asisten Pembimbing Kemasyarakatan. The Functional Positions Pembimbing Kemasyarakatan consist of Pertama, Muda, and Madya levels.

\subsubsection{The Practice of Diversi In Bapas Pekalongan}

Based on information from the Head of Child Client Guidance (later on called BKA) Bapas Kelas II Pekalongan, the Correctional Center has carried out quite a lot of Diversi to Children in Confront with the Law. In the monthly report by Bapas Pekalongan, it is stated that In May 2020, Bapas Kelas II Pekalongan received 14 (fourteen) requests of social research for diversi in juvenile criminal cases.[1]

Of the 14 (fourteen) cases handled by Bapas Kelas II Pekalongan in May 2020, 10 (ten) of the children are still in school and are obeying the rules to participate in the learning process from home so that the diversi process is sought to solve it. The data is displayed in table form as follows:

Table III: State the source of data and year

\begin{tabular}{|c|c|c|c|c|}
\hline NO & BULAN & $\begin{array}{c}\text { DIVERSI } \\
\text { BERHASIL }\end{array}$ & $\begin{array}{c}\text { DIVERSI } \\
\text { GAGAL }\end{array}$ & $\begin{array}{c}\text { JUMLAH } \\
\text { DIVERSI }\end{array}$ \\
\hline 1. & Januari & 7 & 0 & 7 \\
\hline 2. & Februari & 3 & 1 & 4 \\
\hline 3. & Maret & 4 & 1 & 5 \\
\hline
\end{tabular}




\begin{tabular}{|c|c|c|c|c|}
\hline 4. & April & 1 & 0 & 1 \\
\hline 5. & Mei & 10 & 4 & 14 \\
\hline 6. & Juni & 6 & 2 & 8 \\
\hline
\end{tabular}

During the Covid-19 pandemic, diversi at Pekalongan Bapas was still implemented, as a result of the high demand for social research of diversion (penelitian kemasyarakatan) for children as described in the data above. From these requests, some of the processes were successful, but the others were not.

According to Adhi Nurcahyo, Head of BKA Bapas Pekalongan, several factors that affect the unsuccessful diversi are caused by:

a. The victim does not agree to be involved in the Diversi efforts as an alternative to the criminal settlement

b. There is no common ground between victims and children regarding the Diversi agreement, even though they have met in an effort to consensus between victims and perpetrators

c. The bad image of a child who was well known in the community before the crime occurred influences the victim to accept the Diversi agreement.

Based on the example collected in Bapas Pekalongan, if the Diversi was not successfully implemented or an agreement was not met, the criminal process for children would be continued to the next stage. At the next stage, however, both the prosecutor's office and the court will still be looking at the possibility of having Diversi efforts as long as it meets the requirements listed in article 7 of Law Number 11 of 2012 concerning the Juvenile Criminal Justice System, which is not a repetition of a criminal act and the threat of punishment is not more than 7 (seven) years.

In addition, the Diversi effort that has been carried out by Bapas Pekalongan always brings together various parties, including the village government, schools, parents of children, victims, and parents of victims. It is expected that the results of the Diversi agreement can be the best solution for the child and the victims.

However, during the Covid-19 pandemic, many had to change because of the existing situation. These are new challenges that must be resolved by Bapas Pekalongan or perhaps all other Bapas in
Indonesia. According to Kasubsie BKA, several factors prevent the diversi process during this pandemic, namely:

a. Limited coordination between law enforcement officials due to the PSBB policy.

b. There are concerns that the diversi process that brings together the parties is feared to become a new cluster of the spread of covid-19, despite implementing health protocols.

c. Several Social Institutions that are alternative for Child Development besides Child Prison, such as Child Welfare Institutions, Shelters and so on, limit the number of children who enter by requiring information that they are not exposed to Covid-19.

d. Supervision of children who have been successfully diversified becomes constrained because several areas have implemented the PSBB, such as in the City of Tegal. In addition, Bapas Pekalongan Community Advisors must keep themselves from being exposed to Covid19 because there are many clients who must be supervised, both children and adults.

These factors have indeed hampered the implementation of diversi at Bapas Pekalongan, but there are still ways to implement them during this pandemic. Because the implementation of diversion is progress in criminal justice in Indonesia that more reflects the values of justice based on the principle of restoration

\subsection{The Effectiveness of Applying Diversi In Bapas Kelas II Pekalongan During Covid-19 Pandemic}

The effectiveness in the context of law means that any legal effort creates a condition or situation where everything goes according to legal expectations.[6]

The effectiveness of a legal product can be measured from its implementation so far, especially the assessment of whether or not the objectives of the legal product have been achieved. Law Number 11 of 2012 concerning the Juvenile Criminal Justice System, for instance, is a legal product and its effectiveness can be seen from its implementation so far.

According to Soerjono Soekanto, the effectiveness of a legal product can be seen from 5 (five) factors that are interrelated and become a 
benchmark for legal products. The five factors are[7]:
a. Regulatory Factors (Law)
b. Law Enforcement Factors by Officials
c. Law Enforcement Facility Factors
d. Social and Community Factors
e. Cultural Factors

The effectiveness of the application of diversi as a mandate of Law Number 11 of 2012 concerning the Juvenile Criminal Justice System to realize its objectives can be seen from the following factors.

a. Regulatory Factors (Law)

Normatively, a law or regulation product will be determined by 3 (three) main elements, namely:

1) Juridical element, that every legal product has a strong juridical foundation under the provisions of laws and regulations. In this context, the application of diversi is a legal product of Law Number 11 of 2012 concerning the Juvenile Criminal Justice System, which is then reinforced in Government Regulation Number 65 of 2015 concerning Diversi Determination and Decision Making. It is subsequently strengthened again by the regulations under it, both in the Supreme Court Regulation, the Circular Letter of the Attorney General's Office, and the Letter of the Chief of the Indonesian Police. In addition, Law no. 11 of 2012 is ratifies several international regulations, such as the Convention on the Rights of the Child, the UN minimum standard regulations for the implementation of juvenile justice-the Beijing Regulations, and the UN Regulations for the Protection of Children who are deprived of their liberty.

2)Sociological element, that every legal product must be accepted by the society where the law is applied. In this context, the application of diversi has been a national discourse since 2012, so that there has been much discussion about diversi throughout Indonesia. Law enforcement officials are quite aggressively socializing this legal product to all levels of society, both directly and through various media. However, there is still a debate in which some parties are still not agreeing with the diversi attempt as a legal product.
3)Philosophical elements, that every legal product must contain the values of the national philosophy, namely Pancasila. In this context, the application of diversi based on the principle of restorative justice can reflect the values contained in Pancasila. The precepts of the Almighty Godhead are manifested in the attitude of being able to forgive one another as fellow servants. Humanitarian precepts that are just and civilized are shown by guarding the human soul against the harshness of punishment by looking for alternative solutions. The precepts of Indonesian Unity are manifested by a cooperative attitude in carrying out the process and believing that the law in this country works properly. Deliberative precepts led by wisdom in representative deliberations are displayed with deliberation efforts to find solutions by consensus. The precepts of social justice for all Indonesian people are realized through a diversi agreement based on a sense of justice according to the victim and the perpetrator

\section{b. Law Enforcement Factors by Officials}

Law enforcement officers in this study are those in charge of the judiciary, the prosecutor's office, the police, and prisons. Law enforcement officials are a sub-structure in society that is mandated to channel their competencies for the realization of legal ideals. Law enforcement officials must also be able to establish communication and get attention from the community so that their existence can be accepted by all levels of society.

In addition, law enforcement officials are required to utilize certain elements of local wisdom to stimulate community participation. It is no less important that law enforcement officials must be good at managing the right time and environment in disseminating legal norms, both new and old. In the end, law enforcement carried out by the authorities does not only include law enforcement, but also peace maintenance. [8]

In the context of applying diversi, law enforcement officials have coordinated and communicated, both at the central and regional levels. The form of communication has been established with the formation of several regulations regarding diversi in each law enforcement agency as a commitment to carry out the mandate of Law Number 11 of 2012. 
In addition, Bapas Pekalongan has participated in several cross-agency coordination, both in the Pekalongan residency area and within Central Java region, by bringing together all elements of law enforcement to equalize perceptions regarding the enforcement of Juvenile Criminal Justice, including discussion of diversi. This means that law enforcement officials have received sufficient information to realize diversi efforts in their respective institutions.

In this study, it is known that several Class II Pekalongan Bapas Community Counselors have participated in the coordination, whether organized by the Regional / City Government, the Attorney General's Office, the Police, and the Regional Office of the Ministry of Law and Human Rights in Central Java. Therefore, information regarding diversi is quite complete and understood by all levels of Bapas Pekalongan officials.

On several occasions, Bapas Pekalongan has been asked by several community organizations to socialize the Juvenile Criminal Justice System, including the issue of diversi. This is an advantage of Bapas Pekalongan in its function as a provider of information to the public about the law.

However, during the limitation period due to the Covid-19 pandemic, some problems ultimately hindered the role of Bapas Pekalongan in coordinating face-to-face with other law enforcement parties regarding diversi efforts. This is a dilemma because on the one hand, every officer must guard himself so as not to become infected with the virus or become a virus transmitter without realizing it,. On the other, there are children's interests that must be prioritized as the mandate of the law. In fact, activities to directly socialize with the community will not exist for some time to come.

\section{c. Law Enforcement Facility Factors}

Law enforcement facilities can be hard or soft. Hard facilities are those in the form of physical entities or in-kind, such as buildings, rooms and so on. In contrast, soft facilities are non-physical support for law enforcement, such as education and training for officials. [7]

Until now, the Pekalongan Bapas environment has provided rigorous facilities to support the implementation of diversi, both in the courtroom and child-friendly space. Also, similar facilities are available in other law enforcement agencies. However, during the Covid-19 pandemic, a problem occurred due to health protocols which required limiting the distance to a few meters, even though there were rooms that became narrow due to the distance restrictions imposed.

While the facilities are soft, several Community Guides of Bapas Pekalongan have attended training and fast education (Diklat) which brings together all elements of law enforcement to equalize perceptions related to the enforcement of Juvenile Criminal Justice, including discussion of diversi. These include the Supreme Court, the Attorney General's Office, the Police, or the Ministry of Law and Human Rights. This means that law enforcers in the Pekalongan District Police have received sufficient information to realize diversi efforts in their respective institutions.

\section{d. Social and Community Factors}

The effectiveness of a legal product can be influenced by the degree of public acceptance and awareness of the legal product. The acceptance and awareness of this law are largely determined by the information and knowledge power possessed by the community. The more information the public gets, the more likely the legal product will be accepted.[7]

In this study, it was found that the Bapas Pekalongan has been asked by community organizations several times to socialize the Juvenile Criminal Justice System, including the issue of diversi. This also includes disseminating information to local government officials.

Even so, there are also people who have not been informed at all, so the Pekalongan District Head maximizes the use of information technology to campaign the importance of diversi based on restorative principles. In addition, if there is an opportunity for the implementation of diversion, the Pembimbing Kemasyarakatan of Bapas Pekalongan will explain to the perpetrators and victims about the purpose of the diversion implementation

e. Cultural Factors

Culture is something that cannot be separated from the pattern of people's lives. Its 
appearance is in line with the presence of a community in a place. Even culture can balance life in the middle of an arid society.

According to Soerjono Soekanto, culture has a function to regulate humans to act according to applicable norms. Therefore, when humans leave the existing culture, they have committed acts that are considered out of the norms, including those classified as criminal.[7]

In the context of Javanese society, the principle of harmony and respect is the moral concept of Javanese society in regulating life behavior towards others. Its manifestation is to stay away from actions called molimo (five things), namely mendem (drinking alcohol), madat (addiction drugs ), madon (playing women), main (gambling), and mangan (greedy).[9]

When someone does an act of molimo or it is indicated that it is against harmony, it is an act that is against the norms of Javanese society. As a result, the community will punish the perpetrator, both physical and social punishment in accordance with Javanese culture. Some consequences must be given but still in order to maintain human dignity. There are even redemptive efforts to solve problems that violate these norms, either with the help of customary judges or between individuals. This settlement mechanism departs from a sense of forgiveness from each party.[9]

This means that the Javanese culture, in general, has been accustomed to a culture of forgiveness as a way to resolve cases. In the context of diversi, the element of forgiveness is fundamental to getting a fair agreement for both parties. Therefore, it can be assumed that the Javanese culture can accept diversi as an effort to resolve it without going through a trial.

The research at Bapas Pekalongan revealed that several diversi processes succeeded in reaching an agreement because the victims and the community could apologize to $\mathrm{ABH}$ and care about their growth and development, so they agreed not to put them in prison.

Based on the data described above, it can be said that the Correctional Center has implemented diversi well, even during the Covid-19 pandemic. Even in terms of legal effectiveness, according to Soerjono Soekanto, both in terms of the regulation (law), law enforcement officials, facilities and facilities, social society, and culture have fulfilled all elements, although they have some obstacles.

These problems can be solved so that the implementation of diversi can be more optimal in the future. Some of the factors that hinder the application of the diversi can be resolved in the following ways, namely:

a. Limited coordination between law enforcement officials due to the PSBB policy may be resolved by using information technology, such as zoom applications, whereby, video call by WhatsApp and others. However, there is still a feeling of discomfort with the use of the media, because coordination is not just a face-to-face issue, but it is more essential to create a common understanding that supports a better application of diversi.

b. Concerns that the diversi process is feared to become a new cluster of the spread of covid-19, despite implementing health protocols, can also be overcome by the use of information technology, but it still has consequences on the common perception that will be generated. Therefore, any efforts to conduct face-to-face meeting still have to be carried out by tightening health protocols and providing more space for meetings with enough people.

c. Several Social Institutions which are alternatives for child development other than LPKA limit the number of enrollments of children by requiring that they have received information that they are not exposed to Covid-19. This is done despite the economic capacity of some $\mathrm{ABH}$ parents is classified as underprivileged, especially during the Covid-19 pandemic. However, in the past, Bapas Pekalongan coordinated with one of the Social Institutions to receive children whose results of the diversi agreement had to be fostered at the Social Institution on the condition that they had carried out a rapid test. In addition, Bapas Pekalongan has also collaborated with religious institutions that are ready to help foster $\mathrm{ABH}$ around the Batang Regency area. This will make it easier for the Pekalongan District Heads to recommend a place for guidance not far from where the children live. 
d. Supervision of children who have been successfully diversified becomes constrained because several areas have implemented the PSBB, such as in the City of Tegal. In addition, Bapas Pekalongan Community Advisors must keep themselves from being exposed to Covid19 because of the large number of clients that must be supervised, both children and adults. For this problem, alliance and cooperation with village government officials can be an alternative solution. Children who get the results of the diversi agreement can be proposed to undergo social services in the village as an alternative form of punishment under the supervision of the Bapas Pekalongan Community Advisor with the local Village Government Officials

\section{CONCLUSION}

Based on the data and analysis previously described, it is known that the Correctional Center has implemented diversi well, even during the Covid-19 pandemic. In fact, it can be said that it runs quite effectively in terms of legal effectiveness. According to Soerjono Soekanto, this occurs in terms of the regulation, law enforcement officials, facilities, social society, and culture.

However, solutions are required so that the implementation of diversi in the future could be improved, such as limited face-to-face coordination with other law enforcement officials, constrained supervision during the implementation of the results of the diversi agreement, and restrictions on access to social institutions. This is intended as a preventive effort from the spread of the Covid-19 outbreak.

The recommendations offered to solve this problem can be in the form of strengthening information technology as a solution to the coordination of law enforcement officials, as well as maximizing the function of village government as a partner to oversee the results of a diversi agreement that cannot be proposed to enter into Social Institutions due to social restrictions during the pandemic.

\section{REFERENCES}

[1] Interview with Adhi Nucahyo, Selaku Kasubsie Bimbingan Klien Anak Bapas Pekalongan, "Wawancara dengan Adhi
Nucahyo, Selaku Kasubsie Bimbingan Klien Anak Bapas Pekalongan,” Sep. 25, 2020.

[2] A. Ouss, "Prison as a School of Crime: Evidence from Cell-Level Interactions," SSRN Electron. J., 2011, doi: 10.2139/ssrn.1989803.

[3] N. K. Ratna, Metodologi Penelitian (Kajian Budaya dan Ilmu Sosial Humaniora Pada Umumnya). Yogyakarta: Pustaka Pelajar, 2010.

[4] Status Pelaporan Klien Bapas Perkanwil, "Status Pelaporan Klien Bapas Perkanwil," smslap.ditjenpas.go.id, Oct. 12, 2020. http://smslap.ditjenpas.go.id/public/bps/status/ monthly (accessed Oct. 12, 2020).

[5] "Sistem Informasi Perumahan, Kawasan Permukiman dan Pertanahan Provinsi Jawa Tengah.”

http://si.disperakim.jatengprov.go.id/umum/ko ndisi_geo (accessed Oct. 10, 2020).

[6] W. Yudho and H. Tjandrasari, "Efektivitas Hukum Dalam Masyarakat," J. Huk. Pembang., vol. 17, no. 1, Art. no. 1, Jun. 2017, doi: 10.21143/jhp.vol17.no1.1227.

[7] R. A. Novita and A. B. Prasetyo, "Efektivitas Pelaksanaan Undang-Undang Nomor 2 Tahun 1960 Tentang Perjanjian Bagi Hasil Tanah Pertanian (Tanah Kering) Di Desa Bringin, Kecamatan Bayan, Kabupaten Purworejo," vol. 6, p. 12, 2017.

[8] H. Y. Parmahan Sibuea, "Penegakan Hukum Pengaturan Minuman Beralkohol (Law Enforcement Regulation of Alcoholic Beverages) | Sibuea | Negara Hukum: Membangun Hukum untuk Keadilan dan Kesejahteraan," 2016. https://jurnal.dpr.go.id/index.php/hukum/articl e/view/926 (accessed Oct. 07, 2020).

[9] N. Surbakti, Peradilan Restoratif Dalam Bingkai Empiri, Teori dan Kebijakan. Yogyakarta: GENTA Publishing, 2014. 